\title{
Effectiveness of Surgical hand Washing with Chlorhexidine, Providone iodine and Alcohol on Reducing the Microorganisms on the Hands: A Systematic Review
}

\section{Haris Widodo, Tiffany Gita Sesaria, M. Ruli Maulana and Nyein Moh Moh Myint}

Faculty of Nursing, Universitas Airlangga, Surabaya, Indonesia

\begin{abstract}
Background: Postoperative infection is one of the causes of mortality and the hands of the surgical team are the most common cause. According to the The Center for Disease Control and Prevention (CDC), proper hand washing can reduce the occurrence of nosocomial infections by up to $30 \%$. The aim of this study is to determine the effectiveness of surgical hand washing using chlorhexidine, providone iodine and alcohol in reducing the microorganisms on the hand.
\end{abstract}

Method: The data was collected from the following electronic databases: Science Direct, Springer link, Scopus and ProQuest. The search obtained 11 articles in accordance with the inclusion criteria and we obtained the literature in full text form.

Result: The results of the study found three articles that mentioned hand washing with an alcohol hand rub as being more effective than iodine and chlorhexidine providone. There was one article described that both alcohol hand rub and chlorhexidine are more effective than iodine providone, Another article mentioned that chlorhexidine, providone iodine and alcohol hand rub were equally effective at reducing microorganisms contaminating the hand.

Conclusion: The conclusion of the study is that surgical hand washing using chlorhexidine, providone iodine and alcohol are all effective at reducing microorganisms.

\section{ARTICLE HISTORY}

Received: Dec 26, 2019

Accepted: Dec 31, 2019

\section{KEYWORDS}

surgical; hand washing; chlorhexidine; providone iodine; alcohol; microorganism

\section{CONTACT}

Gevi Melliya Sari

$\triangle$ haris.widodo-

2018@fkp.unair.ac.id

$\equiv$ Faculty of Nursing, Universitas

Airlangga, Surabaya, Indonesia

Cite this as: Widodo, H., Sesaria, T.G., Maulana, M.R., \& Myint, N. M. M. (2019). Effectiveness of Surgical hand Washing with Chlorhexidine, Providone iodine and Alcohol on Reducing the Microorganisms on the Hands: A Systematic Review. Jurnal Ners, 14(3si), 112-115. doi:http://dx.doi.org/10.20473/jn.v14i3(si).17013

\section{INTRODUCTION}

Healthcare-associated infection (HCAI) / nosocomial infection is an infection that occurs when the patient is in the hospital and it is caused by exposure to microorganisms during the delivery of health care services(Gaspar et al., 2018). This infection is a serious problem for hospitals because it can increase the morbidity and mortality rate of the patients and treatment may be a little bit difficult because of bacterial resistance to antibiotic drugs. One of the nosocomial infections is surgical site infection. This is one of the causes of mortality in patients after surgery. The most common cause is the hands of the surgical team(Abdollahi, Tabrizi, Jodati, Safaie, \& Moradi-joo, 2017). Perioperative hand hygiene is one of the most critical factors affecting the risk of surgical site infection (SSI) as well as the safety of the medical
staff(Tsai, Lin, Huang, Loh, \& Wen, 2016). The hands of the surgical team are known to be the most important source of micro-organisms from the skin during surgery(Ghorbani, Shahrokhi, Soltani, Molapour, \& Shafikhani, 2012). Staff, when preparing for surgery, must decontaminate their hands prior to donning sterile gowns and gloves in order to significantly reduce the number of transient and resident micro-organisms on their hands. This is so then the microorganisms due to the skin flora are not transmitted to the patient during surgery. An effective way to reduce the number of micro-organisms is to undertake surgical hand scrub(Ghorbani et al., 2012).

A study conducted in 16 European countries identified that $20 \%$ of all notified healthcareassociated infections were related to surgical procedures(Gaspar et al., 2018). In the United States, $38 \%$ of all nosocomial infections were due to surgical 
site infection (SSI). In Florida, SSI represented onethird of all cases of healthcare-associated infection(Gaspar et al., 2018). SSI in the United Kingdom was around $10 \%$ with a cost of up to 1 million pounds per year and length of stay increased to 7-10 days. WHO surveys showed that the incidence of SSI in the world ranged from $5 \%$ to $34 \%$. Based on the data from the WHO, $40 \%$ of infections that occur in the health care setting can be prevented. Surgical hand wash preparation is recommended by both the Center for Disease Control and Prevention (CDC) and the WHO for preventing SSI in all kinds of surgical procedures. According to the CDC, proper hand washing can reduce the occurrence of nosocomial infections (HCAI) to 30\%(Abdollahi et al., 2017). The application of surgical hand washing is recommended by the CDC and WHO to prevent SSI in all types of surgical procedure(Gaspar et al., 2018). There are several methods of surgical hand washing; there is dry-fast scrubbing and traditional water-based scrubbing(Chen, Chou, Huang, \& Tang, 2014). Surgical hand washing can be done using $4 \%$ clhorhexidine, providone iodine and also $1 \%$ chlorhexidine gluconate and $61 \%$ ethyl alcohol. The purpose of this systematic review was to determine the effectiveness of surgical hand washing using chlorhexidine, providone iodine and alcohol on reducing microorganisms on the hands.

\section{MATERIALS AND METHODS}

\section{Research Design}

This study used a systematic review design, with a questioning search: "What is the effectiveness of a surgical hand washing using chlorhexidine, providone iodine and alcohol on reducing microorganisms on the hand?"

\section{Search Strategy}

The PICOT framework was used in searching for articles that were in accordance with the theme of the systematic review. PICOT can be described as follows: Population - operating room staff; Intervention - the effectiveness of the use of chlorhexidine, providone iodine and alcohol in surgical scrubs; Control -; Outcome - reducing organisms; Time: 2012 - 2018 using the keywords 'surgical scrubs', 'scrubbing' and 'microorganisms'.

\section{Inclusion and Exclusion Criteria}

The inclusion criteria in this review were that they could be an experimental study and nonexperimental study published from 2012 to 2018, where the participants were nurses and doctors, where the language used was English and where it focused on surgical hand washing before surgery. The exclusion criteria were studies that did not involve hand hygiene before surgery.

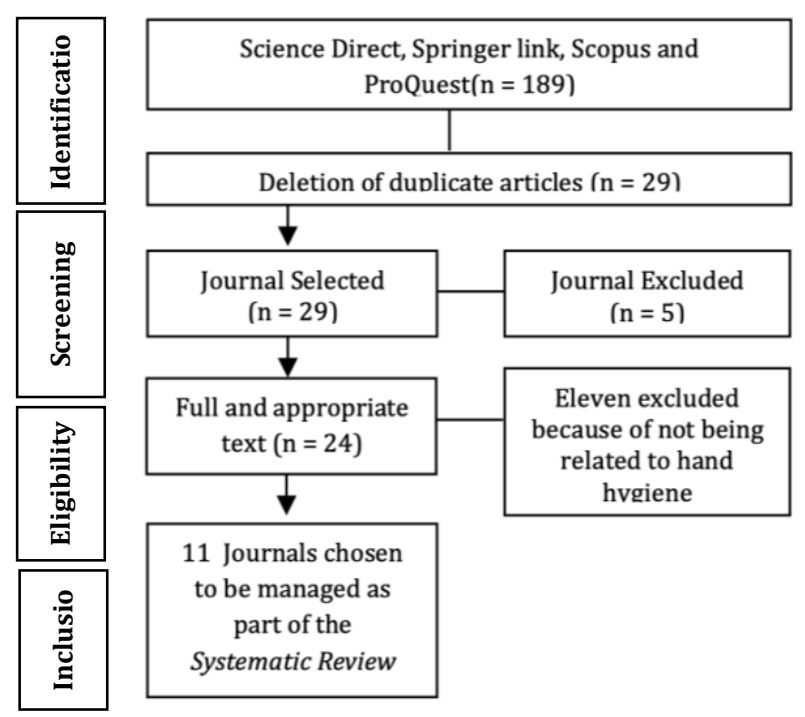

Figure 1. Literature Search Flow

\section{Article Searching Process}

The searching of the articles was done using the keyword 'surgical scrubs', 'scrubbing' and 'microorganisms' in accordance with the PICOT method that was determined and we also used the Boolean logic search method on the Ebscho, Science Direct, Springer link, Scopus and ProQuest databases with a time limitation of 2012 - 2018. In the search process, 189 articles were found and 11 articles were in accordance with the inclusion criteria to be explored further. The complete explanation can be seen in Table 1.

\section{RESULTS}

The systematic review obtained 11 selected articles originating from Brazil, Australia, Taiwan, Iran, the USA and Austria. The results of the systematic review and the scoring of all 11 articles have been attached to the existing Matrix in Table 2. It was found that 9 journals were of good quality and that two journals had moderate quality. The number of samples varied between 20 - 6344 respondents. The measuring instruments used in all of the studies included observation sheets, questionnaires and assessment sheets.

We have showed the results referring to the use of chlorhexidine, providone iodine and alcohol at reducing the microorganisms on the hands in Table 2.

\section{DISCUSSION}

\section{Providone Iodine}

Providone iodine is a material consisting of prolyvinilpyrolidone. It is an antimicrobial, and it leads to the iodination and oxidation of the molecular membrane and cytoplasm of an organism(Collection, 2003). In a study conducted by Edlich et al (1969), they examined a wound infected with staphylococcus aerues. The wound had providone iodine applied for 5 minutes followed by irrigation with normal saline. The infected wound showed improvement. The 
Table 2. List of Articles About the Use of Chlorhexidine, Providone Iodine and Alcohol

\begin{tabular}{|c|c|c|}
\hline $\begin{array}{l}\text { Investigators, year, country } \\
\text { study design }\end{array}$ & Antiseptic compared & Result \\
\hline $\begin{array}{l}\text { Gilberto et al, 2018, Brazil(Gaspar } \\
\text { et al., 2018) } \\
\text { Quasi-experimental Study }\end{array}$ & $\begin{array}{l}\text { - } 2 \% \text { Chlorhexidine } \\
\text { - Alcohol }\end{array}$ & $\begin{array}{l}\text { Washing your hands with alcohol is more } \\
\text { effective at reducing microbes and it takes a } \\
\text { shorter time than } 2 \% \text { chlorhexidine }\end{array}$ \\
\hline $\begin{array}{l}\text { JD Howard et al, 2014, } \\
\text { Australia(Howard, Jowett, Faoagali, } \\
\text { \& Mckenzie, 2014) } \\
\text { Randomized controlled trials }\end{array}$ & $\begin{array}{l}\text { - } 4 \% \text { aqueous chlorhexidine } \\
\text { - } 70 \% \text { isopropyl alcohol }\end{array}$ & $\begin{array}{l}4 \% \text { aqueous chlorhexidine is as effective as } \\
70 \% \text { isopropyl alcohol at reducing the } \\
\text { microorganisms on the hands }\end{array}$ \\
\hline $\begin{array}{l}\text { N.-J. Shen et al.2013, Taiwan(Shen, } \\
\text { Pan, Sheng, \& Chen, 2015) } \\
\text { Prospective observational study }\end{array}$ & $\begin{array}{l}\text { - } 1 \% \text { chlorhexidine gluconate } \\
\text { and } 61 \% \text { ethyl alcohol } \\
\text { - Gluconate } 4 \% \\
\text { chloehexidine }\end{array}$ & $\begin{array}{l}\text { Wash with alcohol is } \\
\text { effective compared with chlorhexidine }\end{array}$ \\
\hline $\begin{array}{l}\text { Jui-Chen Tsai, RN, MSN et al, 2016, } \\
\text { USA(Tsai et al., 2016) } \\
\text { Randomized Controlled Trial }\end{array}$ & $\begin{array}{l}\text { - } 4 \% \text { chlorhexidine } \\
\text { - } 10 \% \text { povidone-iodine } \\
\text { - } 1 \% \text { chlorhexidine gluconate } \\
\text { and } 61 \% \text { che Ebahwa thyl } \\
\text { alcohol }\end{array}$ & $\begin{array}{l}\text { Conventional hand washing with } \\
\text { chlorhexidine scrubs and a waterless hand } \\
\text { rub more effective than providone iodine. }\end{array}$ \\
\hline $\begin{array}{l}\text { Fe chen Chiang, et al, 2012, } \\
\text { Taiwan(Rn, Han, Rn, Chen, \& Wei, } \\
\text { 2012) }\end{array}$ & $\begin{array}{l}\text { - chlorhexidine } \\
\text { - alcohol }\end{array}$ & $\begin{array}{l}\text { Waterless scrub hands (alcohol) are equally } \\
\text { able to decrease microorganisms }\end{array}$ \\
\hline $\begin{array}{l}\text { Ghorbany A et al, 2012, } \\
\text { Iran(Ghorbani et al., 2012) } \\
\text { Prospective observational study }\end{array}$ & $\begin{array}{l}\text { - Alcohol } \\
\text { - providone iodine }\end{array}$ & $\begin{array}{l}\text { Equally effective at reducing } \\
\text { microorganisms }\end{array}$ \\
\hline $\begin{array}{l}\text { SH. Chen et al., 2014, Taiwan(Chen } \\
\text { et al., 2014) } \\
\text { Experimental study }\end{array}$ & $\begin{array}{l}1 \% \text { chlorhexidine gluconate } \\
\text { and } 61 \% \text { ethyl alcohol } \\
7.5 \% \\
\text { povidone-iodine }\end{array}$ & $\begin{array}{l}\text { There is no difference in the number of } \\
\text { colonies generated with fast dry-scrubbing } \\
\text { and a standard surgical scrub }\end{array}$ \\
\hline $\begin{array}{l}\text { Brad S, 2016, USA(Oriel, Chen, \& } \\
\text { Itani, 2016) } \\
\text { Retrospective cohort study }\end{array}$ & - Alcohol & $\begin{array}{l}\text { From the results of the research conducted, } \\
\text { it showed that the alcohol-based rub does } \\
\text { not cause surgical site infection }\end{array}$ \\
\hline $\begin{array}{l}\text { Hennig et al.2017, } \\
\text { Germany(Hennig, Werner, Naujox, } \\
\text { \& Arndt, 2017) } \\
\text { Comparative study }\end{array}$ & $\begin{array}{l}\text { Alcohol hand rub }(45 \% \\
\text { ethanol, } 18 \% \text { propanol } \\
\text { and emollients) } \\
\text { B. } 1 \% \\
\text { - Surgical hand scrub } \\
\text { (chlorhexidine gluconate, } \\
61 \% \text { ethanol and } \\
\text { emollients) }\end{array}$ & $\begin{array}{l}\text { Hand washing with alcohol hand rub can } \\
\text { reduce microbes more than using } \\
\text { chlorhexidine gluconate, } 61 \% \text { ethanol and } \\
\text { emollients }\end{array}$ \\
\hline $\begin{array}{l}\text { Suchomel et al.2018, } \\
\text { Austria(Suchomel, Brillmann, } \\
\text { Assadian, Ousey, \& Presterl, 2018) } \\
\text { Experimental study }\end{array}$ & $\begin{array}{l}\text { Surgical glove coated with } \\
\text { chlorhexidine gluconate }\end{array}$ & $\begin{array}{l}\text { Surgical glove coated chlorhexidine } \\
\text { gluconate can reduce hand flora for } 3 \text { hours }\end{array}$ \\
\hline $\begin{array}{l}\text { JY Kawagoe et al.2015(Kawagoe et } \\
\text { al., 2015) } \\
\text { Quasi-experimental Study }\end{array}$ & $\begin{array}{ll}\text { - } & \text { Traditional surgical hand } \\
\text { scrubbing (TSHS) } \\
\text { - } \\
\text { Alcohol-based } \\
\text { formulation (ABF) in }\end{array}$ & $\begin{array}{l}\text { Alcohol-based formulation (ABF) had } \\
\text { excellent/good acceptance by the members } \\
\text { of surgical team. It } \\
\text { results in considerable savings in water and } \\
\text { healthcare }\end{array}$ \\
\hline
\end{tabular}

effectiveness of providone and iodine is also studied by Andrson (1989) and another study also proved that it can kill pseudomonas bacteria (Hand, Weight, Lee, \& Palmer, 2010). The use of iodine providone in hand washing is proven to reduce microorganisms but there is a need to use water a lot and it can cause irritation to the hands.

\section{Chlorhexidine Gluconate (CHG)}

Chlorhexidine is one type of disinfectant and antiseptic solution. Chlorhexidine skin disinfectant is usually used to prepare for surgery. The CHG antiseptic could be more effective than iodine providone. It is active against Gram-positive organisms and Gram-negative react in facultative anaerobic and aerobic solutions, and yeast. It is 
effective against Gram-positive bacteria (in a concentration of $\geq 1 \mathrm{~g} / \mathrm{l}$ ). The concentration was significantly higher (10 to more than $73 \mathrm{ug} / \mathrm{ml}$ ) as required for bacteria and fungi that are Gramnegative. Chlorhexidine is ineffective against the polio virus and adenovirus. The use of CHG to wash hands is proven to reduce microorganisms but you have to use a lot of water which might increase the cost of water for the hospital. Moreover, it can irritate the hands.

\section{Alcohol Chlorhexidine}

Alcohol chlorhexidine is a mixture of alcohol and chlorhexidine. This liquid is very effective at destroying microorganisms. By using this solution, the cost is relatively cheap and effective when used in surgical hand washing.

There are some limitations to this systematic review. There is no unique protocol for evaluating the journals homogeneously, but we observed differences in the sample dimensions, the procedures for recruiting / selecting the journals, and in the inclusion and exclusion criteria for the patients. The journal literature items that we have included in this systematic review are not considered to involve a difference in the time taken when hand washing as carried out by the participants.

\section{CONCLUSION}

Surgical hand washing (scrubbing) is a procedure that must be performed prior to performing a surgical procedure to reduce the risk of surgical site infection (SSI). Especially in hospitals, the operating room needs to set the standard operating procedures (SOPs) in terms of the use of antiseptics for surgical hand washing (scrubbing). The standard of service is to serve as a reference for doctors and nurses in the operating room during surgical hand washing (scrubbing). SOP that heads in the right direction must have been referred to in the literature and in recent studies focusing on patient safety to prevent the occurrence of surgical site infection (SSI). Based on the results of the systematic review, it can be considered that the use of antiseptics is the most effective at meeting the SOP. There are three antiseptics that can be used to reduce the number of microorganisms on the hand. They are alcohol chlorhexidine, chlorhexidine and providone iodine. Through Systematic Review, the authors identified and compared the three antiseptics and which one was more effective to use. The third antiseptic, chlorhexidine alcohol, is the most effective in use and it should be considered because of how effective and efficient it is in terms of functionality and price. In addition to the use of alcohol hand rubs, it is proven to be effective. The time required for hand washing is not too long (2 minutes) and the cost is more affordable.

\section{REFERENCES}

Abdollahi, L., Tabrizi, J. S., Jodati, A., Safaie, N., \& Moradi-joo, M. (2017). Quality of surgical scrub in a heart hospital : Do not take it for granted. Journal of Cardiovascular and Thoracic Research, 9(3), 164-169. https://doi.org/10.15171/jcvtr.2017.28

Chen, S., Chou, C., Huang, J., \& Tang, Y. (2014). Antibacterial effects on dry-fast and traditional water-based surgical scrubbing methods: A twotime points experimental study. 100(June 2013), 179-185. https://doi.org/10.1111/nhs.12082

Collection, M. (2003). The use of povidone-iodine in superficial partial-thickness burns.

Gaspar, G. G., Menegueti, M. G., Lopes, A. E. R., Santos, R. O. C., de Araújo, T. R., Nassiff, A., ... BellissimoRodrigues, F. (2018). Alcohol-based surgical hand preparation: Translating scientific evidence into clinical practice. Antimicrobial Resistance and Infection Control, 7(1), 1-8. https://doi.org/10.1186/s13756-018-0372-7

Ghorbani, A., Shahrokhi, A., Soltani, Z., Molapour, A., \& Shafikhani, M. (2012). Comparison of surgical hand scrub and alcohol surgical hand rub on reducing hand microbial burden. Journal of Perioperative Practice, 22(2), 67-70. https://doi.org/10.1177/175045891202200205

Hand, A., Weight, C. J., Lee, M. C., \& Palmer, J. S. (2010). Issues in Surgical Management Scrub in 3600 Pediatric Urologic Procedures. URL, 76(1), 15-17. https://doi.org/10.1016/j.urology.2010.01.017

Hennig, T. J., Werner, S., Naujox, K., \& Arndt, A. (2017). Chlorhexidine is not an essential component in alcohol-based surgical hand preparation: A comparative study of two handrubs based on a modified EN 12791 test protocol. Antimicrobial Resistance and Infection Control, 6(1), 1-7. https://doi.org/10.1186/s13756-017-0258-0

Howard, J. D., Jowett, C., Faoagali, J., \& Mckenzie, B. (2014). New method for assessing hand disinfection shows that pre-operative alcohol / chlorhexidine rub is as effective as a traditional surgical scrub. Journal of Hospital Infection, 88(2), 78-83. https://doi.org/10.1016/j.jhin.2014.06.013

Kawagoe, J., Toniolo, A., Silva, C., Menezes, F., Hutter, M., Zimmer, P., ... Gonçalves, P. (2015). Alcohol preparation compared to traditional surgical hand antisepsis: acceptance by surgical team at a private hospital in Brazil. Antimicrobial Resistance and Infection Control, 4(S1), 1-2. https://doi.org/10.1186/2047-2994-4-s1-p163

Oriel, B. S., Chen, Q., \& Itani, K. M. F. (2016). A retrospective cohort study examining SDSSIs using VA Surgical Quality Improvement. The American Journal of Surgery. https://doi.org/10.1016/j.amjsurg.2016.09.058

Rn, C. C., Han, C., Rn, C. K., Chen, S., \& Wei, P. (2012). American Journal of Infection Control Effect of surgical site infections with waterless and traditional hand scrubbing protocols on bacterial 
H. WIDODO, ET AL.

growth Scrub time. YMIC, 40(4), e15-e17. https://doi.org/10.1016/j.ajic.2011.09.008

Shen, N., Pan, S., Sheng, W., \& Chen, Y. (2015). ScienceDirect Comparative antimicrobial efficacy of alcohol-based hand rub and conventional surgical scrub in a medical center. Journal of Microbiology, Immunology and Infection, 48(3), 322-328.

https://doi.org/10.1016/j.jmii.2013.08.005
Suchomel, M., Brillmann, M., Assadian, O., Ousey, K. J., \& Presterl, E. (2018). Chlorhexidine-coated surgical gloves influence the bacterial flora of hands over a period of 3 hours. 4-8.

Tsai, J., Lin, Y., Huang, Y., Loh, E., \& Wen, H. (2016). Antiseptic Effect of Conventional Povidone - Iodine Scrub , Chlorhexidine Scrub, and Waterless Hand Rub in a Surgical Room : A Randomized Controlled Trial. https://doi.org/10.1017/ice.2016.296 